\title{
Modern approaches to the problem of values' formation of students' healthy lifestyle in the course of physical training
}

\author{
Imas Y.V. ${ }^{A B C E}$, Dutchak M. V. ${ }^{A B C D E}$, Andrieieva O. V. ${ }^{A B C D E}$, Kashuba V. O. ${ }^{A B C D E}$, \\ Kensytska I. L. ${ }^{A B C D E}$, Sadovskyi O. O. ${ }^{A B C D E}$ \\ National University of Physical Education and Sport of Ukraine, Ukraine.
}

Authors' Contribution: A - Study design; B - Data collection; C - Statistical analysis; D - Manuscript Preparation; E - Funds Collection.

\begin{abstract}
Purpose: $\quad$ to prove, develop and check the model of values' formation of a healthy lifestyle of students in the course of physical training.

Material: $\quad$ students participated in an experiment (males $-\mathrm{n}=108$; females $-\mathrm{n}=120 ; 18-20$ years old).

Results: $\quad$ it is determined the values' formation level of a healthy lifestyle. It is developed the model of students' healthy lifestyle formation. The model includes the purpose, the task, the principles, the stages, the organizational and methodical conditions, stages, the program and criteria of efficiency. The program of extracurricular occupations of physical training is a component of the model. It is defined factors which determine values' formation of a healthy lifestyle of student's youth in the course of physical training. The following indicators were statistically and significantly improved: levels of physical activity, theoretical readiness, and motivation, level of physical health, values' formation of a healthy lifestyle.

Conclusions: $\quad$ The stimulating factors are information and effective basis of justification, forecasting, and development of values formation model of a healthy lifestyle. It is revealed the need for a change of approaches to the modernization of the educational process of physical training for institutions of the higher education.

Keywords: model, values, students, physical training, healthy lifestyle, physical activity.
\end{abstract}

\section{Introduction}

Health maintenance and fulfilling life of citizens is one of the most important purposes of the world community [1]. This displayed in the principles of European policy «About Health 2020» [2]. The health problem of young age persons is called one of the priority activities of the World Health Organization in XXI century [3]. The following recommendations provided according to the results of researches:

- $\quad$ The influence of individual and national factors on self-rated health varies regarding generation. The target generation and the demographic structure of a country should be taken into account to develop more accurate health policies [4];

- REPOPA (REsearch into POlicy to enhance Physical Activity) will increase understanding use of research evidence in different contexts; develop guidance and tools and establish sustainable structures such as networks and platforms between academics and policy makers across relevant sectors [5];

- $\quad$ There is a need for harmonization of surveillance methodologies, indicators and target populations for between-country and over time comparisons. This inventory will serve to feed future discussions within the DEDIPAC-JPI major framework on how to optimize design and identify priorities within surveillance [6];

The data collected under this HEPA (healthenhancing physical activity) monitoring framework provided, for the first time, an overview of the implementation of HEPA-related policies and actions at the national level throughout the EU [7].

Improvement of life quality and population's health

(c) Imas Y.V., Dutchak M. V., Andrieieva O. V., Kashuba V. O.,

Kensytska I. L., Sadovskyi O. O., 2018

doi:10.15561/20755279.2018.0403 level are extremely relevant for Ukraine [8, 9]. Many scientists devoted researches to the theoretical principles of healthy lifestyle's formation [10]. In such researches scientists consider:

- general-theoretical questions of a healthy lifestyle formation in different groups of the population [11, 12];

- the social value of health culture education $[13,14]$;

- $\quad$ the somatic health of youth [15];

- directions of increase in health's level by means of a recreation and rehabilitation [16];

It revealed the high interest of experts in questions of students' involvement in a healthy lifestyle [17]. Authors determine that the main formation criterions of healthy lifestyle values' in students are:

- involving in regular training with physical culture $[18,19]$;

- interesting in obesity prevention and keeping a healthy diet [20, 21];

- health behavior and cardiometabolic risk factors [22];

- lifestyle factors connected with a depression [23];

- level of physical activity knowledge, students' knowledge about healthy and unhealthy nutrition habits and nutrition knowledge [24].

Researchers define the low level of students' physical activity [25, 26]. It is determined that:

- Promoting physical activity (PA) in low- and middleincome countries is an important public health topic as well as a challenge for practice [27];

- The emotional experience is a key aspect when promoting student's well-being from the physical education. [28];

- Physical education programmes should consider what content is delivered and how to effectively integrate 
practical and theoretical content [29].

The available system of students' physical training requires modernization [29]. This problem requires the subsequent studying in the practical sphere.

The purpose of the research is to prove, develop and check the model of values formation of students' healthy lifestyle in the course of physical training.

\section{Materials and methods}

Participants. 228 students participated at the first (stating) stage of the pedagogical experiment (108 males and 120 females, 18-20 years old). 48 students from higher education institutions of Kiev (Ukraine) participated at the second (forming) stage (23 males and 25 females). The control and experimental groups were created at the beginning of the forming experiment. Groups divided by a random method and had no statistically significant differences between indicators at the beginning of the experiment. The first group was experimental (EG), the second group was control (CG). According to ethical standards, students gave the written consent to participation in the experiment. Protocols of experimental studies are supported by the bioethics commission of the university. 14 representatives of higher education institutions with more than 10 years work experience were involved in the experiment.

Organization of the research. Researches performed on bases of higher education institutions of Kiev (Ukraine). At the first stage was studied the motivation of students to respect the basic principles of a healthy lifestyle. It was also defined: value orientations; the level of physical health; the structure of students' incidence rate.

The pedagogical experiment was the main method of a research. The structure of the experiment provided the implementation of state and forming procedures in a certain sequence. The state experiment was introduced for the purpose to obtain the output data. These data were applied for development the formation model of healthy lifestyle's values of students. At this stage carried out the evaluation of health condition and structure of students' incidence rate. Anthropometrical researches of students were carried out by the standard equipment according to standard and unified techniques [30]. Researches of incidence indicators carried out by copying information from primary medical documentation of education institutions (f. 086/O). In addition was considered the number of students' absences due to illness, duration of one case of illness. During studying of incidence indicators processing of the obtained materials was carried out by classes of diseases according to «International Statistical Classification of Diseases and Related Health Problems» (ICD) [31]. Evaluation of health condition was carried out according to the express technique of somatic health evaluation [32]. It was determined the following parameters: strength and vital indexes, Robinson indexes, body weights, Ruffier. Sociological methods of a research (questioning) applied for evaluation of theoretical knowledge level; definition of students' relation to physical training; definition of priorities in the choice of physical activity types. The questionnaire «Evaluation of students' knowledge of health forming activity» was applied for studying and determination of students' theoretical knowledge level. The questionnaire included 34 tests concerning health formation and healthy lifestyle. It was applied the questionnaire «The students' relation to physical training». The questionnaire «Students' motivation to physical training» allowed students to express the relation to physical activity. The evaluation was carried out according to the 5-point grading scale: «1» - I don’t absolutely agree; «2» - it makes no difference to me; «3» - I partially agree; «4» It is rather no than yes; «5» - I am completely agree. The questionnaire «The healthy lifestyle of the student» was directed to the identification of students' lifestyle features. The questionnaire consisted of 69 questions concerned features of nutrition, daily mode, personal hygiene, cold water treatment, psycho hygiene, bad habits, capacity, physical activity. The questionnaire "Your physical health» consisted of 24 questions and defined a role and the place of physical activity in the healthy lifestyle's values formation of student's youth.

It was determined the level of physical activity of students [33]. Calculation of average energy consumption is carried out according to the formula:

$$
\overline{\mathrm{En}}=\sum_{i=1}^{\mathrm{k}} \mathrm{RFA}_{i} \cdot \mathrm{MET}_{i}
$$

where: $\mathrm{k}$ - number of levels; $\overline{E n}$-average energy of consumption, $\mathrm{kkal} \cdot \mathrm{kg}^{-1}$ per day; RFA - physical activity level, c.u.; MET - weight coefficient.

The modified technique of a research [34] became a basis for the development of the evaluation level of value orientations formation. The technique provided testing of students. Each performed task was estimated according to the 5-point grading scale. If the task is performed indistinctly (unsubstantially) - 1 point was given (a percentage indicator -1-20\%). If the performance of a task needed long considering (the answer was illogical) 2 points were given (a percentage indicator - 21-40\%). If the answer was evidential (though not rather accurate) -3 points were given (a percentage indicator - 41-60\%). If the answer was logical (it was carried out without long considering, but difficulties in scientific definitions were observed) - 4 points were given (a percentage indicator - 61-80\%). If the answer of the student was accurate (scientifically constructed, evidential and logically complete) -5 points were given (a percentage indicator - 81-100\%). General evaluation of values' formation level of a healthy lifestyle was: $1-35 \%$ - critical; 36$70 \%$ - sufficient; $71-100 \%$ - high. Technique «Values orientations» [35] applied for the determination of the initial level of a healthy lifestyle principles' formation. The student was given two lists of values (18 items in each list) on the sheets of paper in alphabetical order. The student should rank each value in a list. The least 
important item will take the 18th place. Firstly was given the set of terminal values, and then the set of tool values.

The expert evaluation of values formation factors of a healthy lifestyle was carried out by the method of advantage (ranging) (14 scientists and pedagogical staff of the higher education institutions with more than 10 years of work experience were involved as experts).

The forming pedagogical experiment was carried out at the second stage. The purpose of a forming pedagogical experiment was the introduction and evaluation of the efficiency of values formation model of students' healthy lifestyle. Duration of the experiment was one academic year. The purpose of the experiment was assistance to the formation and development of healthy lifestyle values in students; formation of knowledge and skills to the application of physical culture means for improving the quality of life. The model contained the following stages: basic, organizational, educational and methodical, forming, productive. The basic stage has been directed to the acquaintance with bases of safety measures, the formation of interest to training, acquaintance with basic elements of traditional technique and innovative means of improving and recreational physical activity. The organizational stage included evaluation of the introduction conditions of values' formation model of a healthy lifestyle. Basic and organizational stages were carried out in parallel during the first and second months of the academic year. The educational and methodical stage provided participation of students in the program of physical training. The program contained theoretical and practical parts. Experimental and control group trained according to the traditional program of physical training for the higher education institutions (once a week according to the program and twice a week according to extracurricular program). The frequency rate and duration of training per week for both groups were equal. The choice of means was carried out according to the motives and the interests of students in physical activity types. Participants in the experimental group applied interactive technologies in the course of the training. The pedagogical control was exercised in the course of training. Also, students in the experimental group were offered to keep the electronic diary of health. The Microsoft Corporation "The MSN Health \& Fitness App-now available on iOS and Android" program [36] was installed on an operating system of the mobile phone. Students had the opportunity to expand independently the system of knowledge about formation, preservation, and promotion of health of the personality, to get acquainted with the techniques of selfchecking and self-correction.

The students fixed indicators of a physical condition in the diary. The productive stage included identification of values formation levels of a healthy lifestyle in students. Criteria for the model efficiency of were the following:

- cognitive (level of theoretical knowledge, awareness concerning need of maintaining own health),

- motivational (awareness of need for care of own health, behavioral stereotypes, motivation to sports and improving training),

- valuable (level of value orientations formation to a healthy lifestyle),

- $\quad$ active (level of physical activity, level of attraction to a regular physical activity trainings).

Statistical analysis. Systematization of material and primary mathematical processing were carried out by means of Microsoft ${ }^{\circledR}$ Excel 2010 tables. The well-known ways of transformation the empirical data of questionnaire [37] were applied for results processing.

\section{Results}

Most of the students have fragmental knowledge concerning health maintaining. Insufficient level of students' knowledge is shown in non-compliance with a healthy lifestyle. Only $30 \%$ of females and $25 \%$ of males have rational nutrition.

Less than a third of the interviewed students have the good quality sleep. $60 \%$ of males and $90 \%$ of females regularly follow the rules of personal hygiene. Most of the students miss physical training classes. Only 26\% of males and $10 \%$ of females practice physical activity in the spare time. Physical activity of high level in males is $34 \pm 3,72 \mathrm{~min}$, in females $22 \pm 2,22 \mathrm{~min}$ (tab. 1).

Students defined the main reasons which made interference to the physical training: lack of conditions for training; the insufficient level of theoretical knowledge; features of the emotionally strong-willed sphere of the personality. Students demonstrated a negative attitude to physical training. It was defined the incentive motives of students to physical training: strengthening of health; receiving satisfaction from training; receiving of good mark or credit; application of the acquired knowledge and skills in everyday life; fashion and prestige of physical

Table 1. Indicators of students' physical activity level

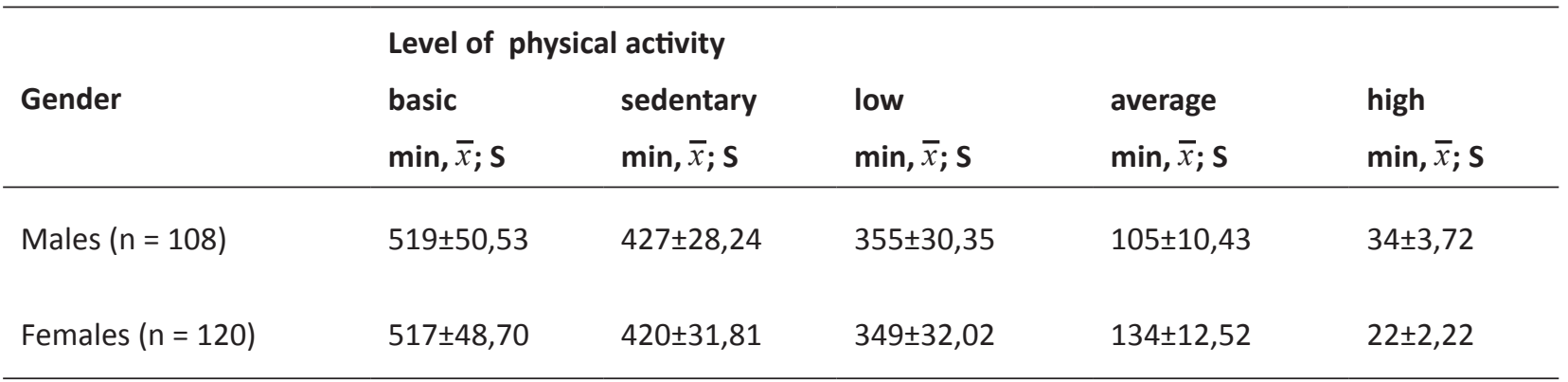


culture training and sport; improvement of mood and health.

In the course of the research was studied hierarchy of terminal (fig. 1) and tool values (fig. 2) of students. In the system of terminal values of males prevails desire of active lifestyle; public calling; entertainments; financial security of life. The females had the following dominated values: entertainments, active lifestyle, the beauty of nature and art.
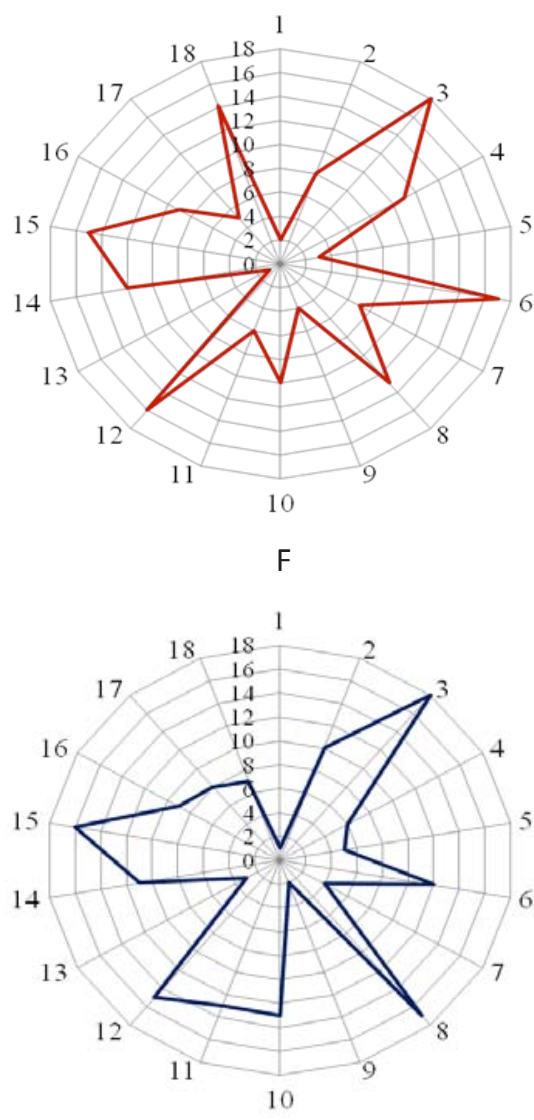

M

Fig. 1. Hierarchy of terminal values of students (males, $\mathrm{n}=108$; females, $\mathrm{n}=120$ ): 1 - active lifestyle; 2 - vital wisdom; 3 - health; 4 - interesting work; 5 - beauty of the nature and art; 6 - love; 7 - financial security of life; 8 - existence of good and loyal friends; 9 - public calling; 10 - knowledge; 11 - productive life; 12 - development; 13 - entertainments; 14 - freedom; 15 - happy family life; 16 - happiness of others; 17 - creativity; 18 - selfconfidence. $\mathrm{M}$ - males; $\mathrm{F}-$ females.
The leading tool values of males are the following: accuracy; ability to keep things in an order; an order on affairs; high requirements to life and high aspirations; selfchecking; diligence. On the last positions there were the independence and high general culture. The leading tool values of females are the irreconcilability to shortcomings in own personality and in others, high aspirations and accuracy.
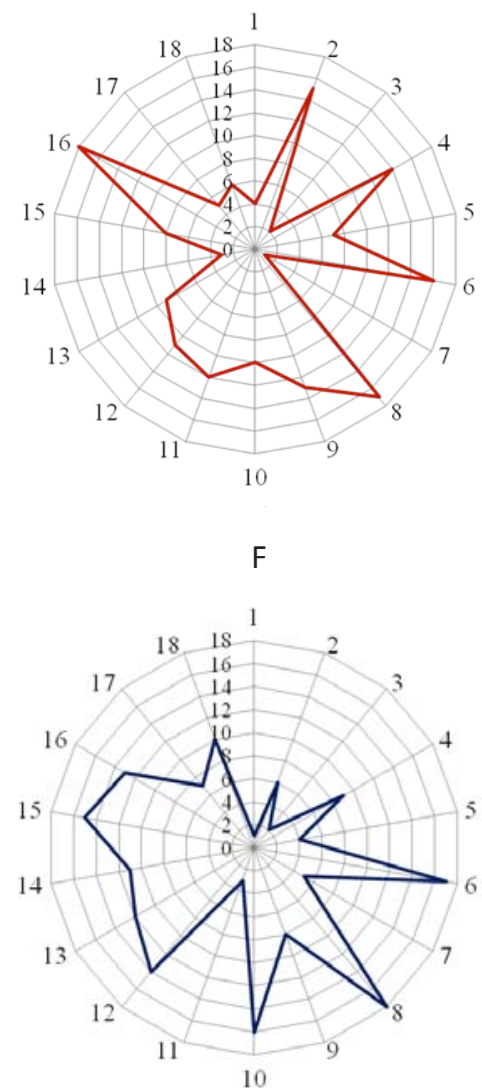

M

Fig. 2. Hierarchy of tool values of students (males, $n=108$; females, $n=120$ ): 1 - accuracy; 2 - social training; 3 - high aspirations; 4 - vivacity; 5 - diligence; 6 - independence; 7 - irreconcilability to shortcomings in own personality and others; 8 - education; 9 - responsibility; 10 rationalism; 11 - self-checking; 12 - courage to persist in own opinion; 13 - strong will; 14 - tolerance; 15 liberality; 16 - honesty; 17 - efficiency on affairs; 18 sensitivity. $\mathrm{M}$ - males; $\mathrm{F}$ - females.

Table 1. Evaluation of indicators of students' physical health

\begin{tabular}{lllll}
\hline \multirow{2}{*}{ Indicator } & \multicolumn{2}{l}{ Male students $(\mathbf{n}=\mathbf{1 0 8})$} & \multicolumn{2}{l}{ Female students $(\mathbf{n}=\mathbf{1 2 0})$} \\
& $\bar{x}$ & $\mathbf{S}$ & $\bar{x} ;$ & $\mathbf{S}$ \\
\hline Body-weight index, $\mathrm{kg} \bullet \mathrm{m}^{-2}$ & 25,95 & 1,47 & 21,58 & 1,52 \\
Robinson index, c.u. & 88,12 & 9,34 & 86,14 & 8,47 \\
Vital index, c.u. & 47,17 & 4,84 & 44,23 & 4,81 \\
Strength index,\%. & 42,00 & 0,40 & 41,00 & 0,30 \\
\hline
\end{tabular}


The high self-esteem of own health by students doesn't coincide with objective data. The majority of students' health indicators belong to below average and low levels (in particular indicators of vital, strength and to Robinson index) (tab. 2).

In the structure of female students' incidence (fig. 3) prevailed the following: diseases of the digestive system (25\%); contagious and parasitic diseases (11,67\%); sensory processing disorder $(11,67 \%)$ and respiratory diseases $(10 \%)$; skin diseases $(8,33 \%)$; disease of genitourinary system $(8,33 \%)$. In males prevailed: diseases of the digestive system (31, 48\%); sensory processing disorder (9,26\%); skin diseases (9,26\%); musculoskeletal disorders (9,26\%); nervous disorders (7,41\%); respiratory diseases $(7,41 \%)$.

It is established the high frequency of students' incidence and chronic diseases. Most of the students don't pay a lot of attention to the formation of own health. It is expressed in: chaotic nature of a daily routine; noncompliance with a rational nutrition and physical activity; the existence of addictions.

Males have the following levels of a healthy lifestyle formation: sufficient - 3,7\%; satisfactory - 20,37\%; critical $-75,93 \%$. Females have the following levels of a healthy lifestyle formation: sufficient $-2,5 \%$; satisfactory - 25\%; critical - 72,5\%. The received results became the background for the development of values formation model of students' healthy lifestyle.

It is revealed the limiting and stimulating factors of values formation of students' healthy lifestyle by means of expert evaluation. The major limiting factors are:
- limitation of knowledge concerning opportunities for improving and recreational physical activity in values formation of a healthy lifestyle $(57,1 \%)$;

- $\quad$ lack of the evidence-based model of values formation of a healthy lifestyle in the course of physical training (28,6\%);

- $\quad$ lack of the appropriate system of pedagogical control $(14,3 \%)$.

Assessment of experts was coordinated $-\mathrm{W}=0,93$ at $\mathrm{p}<0,01$.

Among the stimulating factors, experts defined the following ( $\mathrm{W}=0,91$ at $\mathrm{p}<0,01)$ :

- development of the accurate organizational model and methodical maintenance of educational and extracurricular forms of physical training $(57,1 \%)$;

- creation of the corresponding conditions for ensuring regular physical activity of students $(21,4 \%)$;

- providing students' free choice of physical activity types according to their interests, requirements, and opportunities $(14,3 \%)$.

Introduction of the model in process of physical training allowed to achieve the following results. The theoretical knowledge level of the experimental group students increased. The number of experimental group students with the initial theoretical knowledge level of a healthy lifestyle decreased by $30 \%$. The number of students with a high level of knowledge increased (by $8,3 \%$ ). It is a recorded increase (by $250 \%$ ) the part of experimental group students with the high level of practical abilities. It wasn't observed the significant changes in these indicators in students of the control

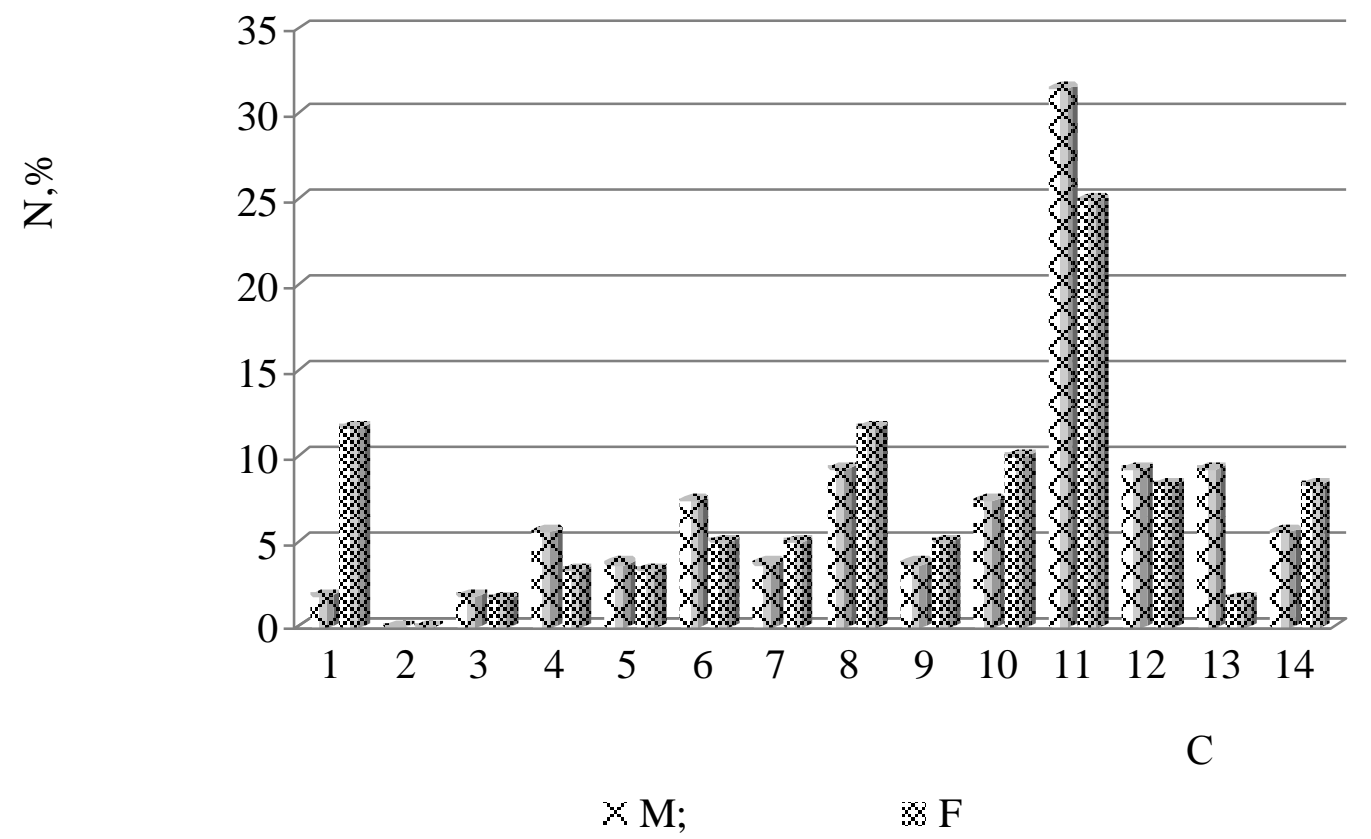

Fig. 3. Structure of incidence of the studied contingent: $N$ - number of students, $\%$; - class of disease; $M-$ males; F-females. 1 - contagious and parasitic diseases; 2 - new growth; 3 - blood diseases; 4 - diseases of the endocrine system; 5 - mental disorders; 6 - nervous disorders; 7 - eye diseases; 8 - ear diseases; 9 - blood circulatory system diseases; 10 - respiratory diseases; 11 - diseases of the digestive system; 12 - skin diseases; 13 - musculoskeletal disorders; 14 - disease of genitourinary system. 
group. The motivation for physical activity training increased in experimental group students after the experiment. The part of experimental group students with the high level of motivation increased by $25 \%$. Among them weren't students with the initial level of motivation to a healthy lifestyle. Level of students' physical activity in both groups increased. The positive changes were also in physical condition indicators of both groups. The students of the experimental group had statistically and significantly higher attitude to health at the end of the experiment (for $n 1=24, n 2=24, p<0,01$ ). In students of control, group indicator increased in: $4,17 \%$ - in comparison with sufficient level; $12,5 \%$ - in comparison with satisfactory level. It happened due to the decrease of a part of students with the critical formation level of a healthy lifestyle (by 16,67\%). In the experimental group, the part of students increased by $4,17 \%$ - in comparison of with high, $41,67 \%$ - in comparison with sufficient level, $12,5 \%$ - in comparison with the satisfactory formation level of a healthy lifestyle. It is determined the decrease of a part of experimental group students with critical formation level (in 58,33\%). Results of a research testified positive changes in values formation indicators of a healthy lifestyle of experimental group students. The received results defined expediency of the simulated process of values formation of students' healthy lifestyle in the course of physical training.

\section{Discussion}

Received results confirm researches of authors concerning need of values formation of a healthy lifestyle $[12,14]$ and the recreational culture of students [38]. It is confirmed the data concerning the insufficient efficiency of physical training organization in higher education institution [26]. According to the results of our researches were expanded data [14] concerning approaches to modernization the physical training educational process in the higher education institutions. It was defined factors which determine values formation of a healthy lifestyle of student's youth in the course of physical training. Stimulating factors are information and effective basis of justification, forecasting, and development of values formation model of a healthy lifestyle.

Our data supply the results of specialists' research devoted to students' motivation to physical training [38], evaluation of their physical health and physical activity levels [39]. We defined the incentive motives of students to physical training. Analysis of these motives will increase the efficiency of physical training educational process. It is expanded the results of a research concerning the students' relation to a healthy lifestyle [40]. It is determined the considerable divergence between the declared value of health, a healthy lifestyle and behavioral intentions of student's youth on the basis of the analysis of these empirical researches.

Organization features of the active leisure of students are proved in the research of Sadovs'kij O.O. [38]. We detailed information concerning quantitative and qualitative characteristics of spare time spending by student's youth. Active recreation on the weekend, walks and outdoor games are usually only for $27,8 \%$ of males and $23,3 \%$ of females.

Our research confirmed and expanded scientific data [32] concerning the practical absence of students with the safe health level. According to the majority of health indicators, students have considerable deviations. It is established the high frequency of incidence in the course of the academic year, the existence of chronic diseases. Similar data are revealed in other researched [41].

Low health level, high incidence of students, induced us to new researches devoted to the problem of youth activization in a healthy lifestyle education. It is proved that insufficient physical activity is one of the reasons for students' health condition deviations. It is confirmed the necessity of students physical activity optimization.

It is specified the developments [11] devoted to the effective application of the information technologies in the improvement of students' quality of the study, improvement of youth theoretical readiness level. Improvement of youth theoretical readiness level of health formation was promoted to the application of the interactive approach: when information is given to students in the interesting form. It was also expanded the data of other authors [39] and reasonably proved the expediency of values formation of a healthy lifestyle with the application of physical training means. It is improved, expanded and deepened the works of Bojko Iu.S. [34] devoted to the technique of values formation evaluation level of a healthy lifestyle. We improved the criteria of evaluation of values formation level of students' healthy lifestyle. The qualitative and quantitative characteristic of their formation levels is also revealed (high, sufficient, satisfactory, critical).

Questions of students' health culture formation in extracurricular time in the course of physical training were investigated in the research [41]. We confirmed results of research that of values formation of a healthy lifestyle has the best opportunities in extracurricular work. It is proved, developed and approved the values formation model of students' healthy lifestyle in the course of physical training. The feature of the offered model is the developed program. The program included interactive technologies and provided application of methods of the electronic, mobile, "turned", mixed education. Results of the performed pedagogical experiment proved the efficiency of application the values formation technology of a healthy lifestyle of student's youth. It is proved by the positive influence on physical condition indicators, theoretical readiness, the volume of physical activity, organization of useful leisure and active recreation.

\section{Conclusions}

Received results of researches confirmed the efficiency of the developed model of values formation of students' healthy lifestyle in the course of physical training. This is given the grounds to recommend it for application in the course of students' physical training at the higher education institutions. 


\section{Acknowledgments}

The study has been fulfilled in compliance with the plan of university scientific-research works in 2016-2020 according to the topic of Health, Fitness and Recreation Chair "The theoretically-methodological principles of improving and recreational physical activity of different groups of the population" (state registration number is 0116U001630).

\section{Conflict of interests}

The authors state that there is no conflict of interest.

\section{References}

1. Concept of development of public health system [Internet]. [cited 2018 May 3]. Available from: http://www.kmu.gov.ua/ control/uk/cardnpd?docid=249618799 (in Ukrainian)

2. About Health 2020 [Internet]. [cited 2018 May 3]. Available from: http://www.euro.who.int/en/health-topics/healthpolicy/health-2020-the-european-policy-for-health-andwell-being/about-health-2020

3. Imas YV, Dutchak MV, Trachuk SV. Strategy and recommendations of a healthy lifestyle and physical activity. In: scientific collection WHO. Kiev: Olympic Literature; 2013. (in Russian)

4. Aguilar-Palacio I, Gil-Lacruz AI, Sanchez-Recio R, Rabanaque MJ. Self-rated health in Europe and its determinants: Does generation matter? International Journal of Public Health. 2018;63(2):223-232. doi:10.1007/s00038018-1079-5

5. Aro AR, Bertram M, Hamalainen RM, Van De Goor I, Skovgaard T, Valente A, et al. Integrating research evidence and physical activity policy making-REPOPA project. Health Promotion International. 2016;31(2):430-439. doi:10.1093/ heapro/dav002

6. Bel-Serrat S, Huybrechts I, Thumann BF, Hebestreit A, Abuja PM, de Henauw S, et al. Inventory of surveillance systems assessing dietary, physical activity and sedentary behaviours in Europe: a DEDIPAC study. European Journal of Public Health. 2017;27(4):747-755. doi:10.1093/eurpub/ckx023

7. Breda J, Jakovljevic J, Rathmes G, Mendes R, Fontaine $\mathrm{O}$, Hollmann S, et al. Promoting health-enhancing physical activity in Europe: Current state of surveillance, policy development and implementation. Health Policy. 2018;122(5):519-527. doi:10.1016/j.healthpol.2018.01.015

8. Dutchak MV. The paradigm of health-enhancing physical activity: theoretical proving and practical application. Teoriia i metodika fizichnogo vikhovannia i sportu, 2015;2:44-52. (in Ukrainian)

9. The national strategy of improving physical activity in Ukraine till 2025 "Physical activity - a healthy lifestyle the healthy nation" [Internet]. [cited 2018 May 3]. Available from: http://zakon0.rada.gov.ua/laws/show/42/20160 (in Ukrainian)

10.Andrieieva OV, Kensytska IL. The limiting and stimulating factors of values formation of students' healthy lifestyle. Molodizhnij naukovij visnik Skhidnoievropejs'kogo nacional'nogo universitetu imeni Lesi Ukrainki, 2017;26:3742. (inUkrainian)

11.Ivanchikova SM. Formation of students' health culture by means of fitness in extracurricular work of the higher education institution. Cand. Diss. Starobelsk; 2017. (in Ukrainian)

12.Poscia A, Moscato U, La Milia DI, Milovanovic S, Stojanovic J, Borghini A, et al. Workplace health promotion for older workers: a systematic literature review. Bmc Health Services Research. 2016;16. doi:10.1186/s12913-016-1518-z

13.Moskalenko N, Korzh N. The technology of forming the valuable relation to self-employed physical training. Sportivnij visnik Pridniprov'ia, 2016;1:201-206. (in
Ukrainian)

14. Whitfield M, Bhanbhro S, Green G, Lewis K, Hindle L, Levy C. Developing a framework for estimating the potential impact of obesity interventions in a European city. Health Promotion International. 2016;31(3):684-691. doi:10.1093/ heapro/dav019

15.Jagiełło M, Iermakov SS, Nowiński M. Differentiation of the somatic composition of students physical education specialising in various sports. Arch Budo Sci Martial Art Extreme Sport, 2017;13:63-70.

16.Kriventsova I, Pashkevych S, Iermakov S, Bartík P, Michal J, Nosko M, Yermakova T. Fitness - aerobic training of 15 - 17 years' age girl students, who have significant risk of deviations in backbone functional state. Journal of Human Sport and Exercise, 2017;12(4), 1289-1297. doi:10.14198/ jhse.2017.124.15

17.Kashuba VO, Futornyj SM, Andrieieva OV. The analysis of application of health saving technologies in the course of physical training of student's youth. Teoriia i metodika fizicheskoj kul'tury, 2012;1:73-81. (in Russian)

18.Andrieieva OV. Katerina UN. Conditions for enhancing extracurricular physical education activity in high education establishments. Ştiinţa culturii fizice, 2014;18(2):64-70.(in Russian)

19.Dutchak MV. Current problems of health formation of student's youth in the context of professional formation of the personality. Profesijne stanovlennia osobistosti, 2013;1:2530. (in Ukrainian)

20.Kwan MY, Arbour-Nicitopoulos KP, Duku E, Faulkner G. Patterns of multiple health risk-behaviours in university students and their association with mental health: application of latent class analysis. Health Promotion and Chronic Disease Prevention in Canada-Research Policy and Practice. 2016;36(8):163-170. doi:10.24095/hpcdp.36.8.03

21.Lam E, Partridge SR, Allman-Farinelli M. Strategies for successful recruitment of young adults to healthy lifestyle programmes for the prevention of weight gain: a systematic review. Obesity Reviews. 2016;17(2):178-200. doi:10.1111/ obr. 12350

22.Many GM, Lutsch A, Connors KE, Shearer J, Brown HC, Ash G, et al. Examination of Lifestyle Behaviors and Cardiometabolic Risk Factors in University Students Enrolled in Kinesiology Degree Programs. Journal of Strength and Conditioning Research. 2016;30(4):1137-1146. doi:10.1519/jsc.0000000000000871

23.Xu Y, Qi J, Yang Y, Wen XZ. The contribution of lifestyle factors to depressive symptoms: A cross-sectional study in Chinese college students. Psychiatry Research. 2016;245:243-249. doi:10.1016/j.psychres.2016.03.009

24. Yahia N, Wang D, Rapley M, Dey R. Assessment of weight status, dietary habits and beliefs, physical activity, and nutritional knowledge among university students. Perspectives in Public Health. 2016;136(4):231-244. doi:10.1177/1757913915609945

25.Andrieieva O, Sadovs'kij O. Physical activity as component of recreational culture of students. Teoriia $i$ metodika fizichnogo vikhovannia i sportu, 2016;1:19-22. (in Ukrainian) 
26.Kashuba V, Kolos M, Rudnytskyi O, Yaremenko V, Shandrygos V, Dudko M, Andrieieva O. Modern approaches to improving body constitution of female students within physical education classes. Journal of Physical Education and Sport, 2017;17(4):2472-2476. doi:10.7752/jpes.2017.04277

27.Barbosa VC, da Silva KS, Mota J, Beck C, Lopes AD. A Physical Activity Intervention for Brazilian Students From Low Human Development Index Areas: A ClusterRandomized Controlled Trial. Journal of Physical Activity \& Health. 2016;13(11):1174-1182. doi:10.1123/jpah.20160113

28.Romero-Martin MR, Fleta G, Serra M, Burgues L. Influence of motor practices on university students' emotional state. Revista Internacional De Medicina Y Ciencias De La Actividad Fisica Y Del Deporte. 2017;17(67):449-466. doi:10.15366/rimcafd2017.67.004

29.Spittle M, Spittle S. Content of curriculum in physical education teacher education: expectations of undergraduate physical education students. Asia-Pacific Journal of Teacher Education. 2016;44(3):257-273. doi:10.1080/135986 6x.2015.1080813

30.International Standards for Anthropometric Assessment. 2001. [Internet] 2017 Nov 1 [updated 2018 Jan 1; cited 2017 Nov 8]. Available from: http://www.ceap.br/material/ MAT17032011184632.pdf

31.International Statistical Classification of Diseases and Related Health Problems (ICD). 2018. [Internet] 2018 Jun 18 [updated 2018 Jun 18; cited 2018 Jun 18]. Available from: http://www.who.int/health-topics/internationalclassification-of-diseases

32.Apanasenko GL, Popova LA. Individual health: theory and practice. Introduction into the theory of individual health.
Kiev: Medicine; 2011. (in Russian)

33.Davidenko EV, Raslan Masaud. Technique of a Fremengemsky research of physical activity of the person. Kiev: Olympic Literature; 1999. (in Russian)

34.Bojko IuS. Formation of axiological principles to a healthy lifestyle in students of higher educational institutions. Cand. Diss. Uman; 2015. (in Ukrainian)

35.Rokeach Milton. The Nature of Human Values. New York: The Free Press; 1973.

36.The MSN Health \& Fitness App - now available on iOS and Android. 2018. [Internet] 2018 Jun 18 [updated 2018 Jun 18; cited 2018 Jun 18]. Available from: https://www.msn.com/ en-us/health/wellness/the-msn-health-and-fitness-app-nowavailable-on-ios-and-android/ss-BBgyET8\#image $=1$

37.Paniotto VI, Maksimenko VS. Quantitative methods in sociological researches. Kiev: Phoenix; 2003. (in Russian)

38.Sadovs'kij OO. Formation of recreational culture of student's youth in the course of physical training. Cand. Diss. Kiev; 2017. (inUkrainian)

39. Yarmak O, Galan Y, Hakman A, Dotsyuk L, Teslitskyi Y. The use of modern means of health improving fitness during the process of physical education of student youth. Journal of Physical Education and Sport, 2017; 17(3): 1935-1940. doi:10.7752/jpes.2017.03189

40.Kensytska I. Model of values formation of a students' healthy lifestyle in the course of physical training. Teoriia i metodika fizichnogo vikhovannia i sportu, 2017;4:69-76.(in Ukrainian)

41.Katerina U. Justification of efficiency of introduction of educational and improving complexes in process of students' physical training. Fizichna kul'tura, sport ta zdorov'ia nacii, 2016;1. 66-71. (in Ukrainian)

\section{Information about the authors:}

Imas Y.V.; http://orcid.org/0000-0003-0641-678X; evgeniy.imas@gmail.com; National University of Physical Education and Sport of Ukraine; Fizkulture str., 1, 03150, Kiev, Ukraine.

Dutchak M. V.; http://orcid.org/0000-0001-6823-272X; mvd21@ukr.net; National University of Physical Education and Sport of Ukraine; Fizkulture str., 1, 03150, Kiev, Ukraine.

Andrieieva O. V. (Corresponding author); http://orcid.org/0000-0002-2893-1224; olena.andreeva@gmail.com; National University of Physical Education and Sport of Ukraine; Fizkulture str., 1, 03150, Kiev, Ukraine.

Kashuba V. O.; http://orcid.org/0000-0001-6669-738X; kashubavo@gmail.com; National University of Physical Education and Sport of Ukraine; Fizkulture str., 1, 03150, Kiev, Ukraine.

Kensytska I. L.; http://orcid.org/0000-0003-1020-400X; irynaken@gmail.com; National University of Physical Education and Sport of Ukraine; Fizkulture str., 1, 03150, Kiev, Ukraine.

Sadovskyi O. O.; http://orcid.org/0000-0001-9687-9512; sadovskiyoleksiy@gmail.com; National University of Physical Education and Sport of Ukraine; Fizkulture str., 1, 03150, Kiev, Ukraine.

Cite this article as: Imas YV, Dutchak MV, Andrieieva OV, Kashuba VO, Kensytska IL, Sadovskyi OO. Modern approaches to the problem of values' formation of students' healthy lifestyle in the course of physical training. Physical education of students, 2018;22(4):182-189. doi:10.15561/20755279.2018.0403

The electronic version of this article is the complete one and can be found online at: http://www.sportedu.org.ua/index.php/PES/issue/archive

This is an Open Access article distributed under the terms of the Creative Commons Attribution License, which permits unrestricted use, distribution, and reproduction in any medium, provided the original work is properly cited (http://creativecommons.org/licenses/by/4.0/deed.en).

Received: 20.05.2018

Accepted: 12.06.2018; Published: 23.08.2018 